\title{
Comparative Antioxidant, Antimicrobial and Phytochemical Assesments of Leaves of Desmostachya bipinnata L. Stapf, Hordeum vulgare L. and Drepanostachyum falcatum (Nees) Keng f.
}

Pragya Nepal, Minu Singh, Amina Baniya, Sushma Singh, Hari Krishna Sainju, Rajani Shrestha Department of Biotechnology, Asian Institute of Technology and Management (AITM), Khumaltar, Lalitpur, Nepal

\begin{abstract}
Nepal is rich in varieties of religious plants. The locally used religious plants also carry medicinal importance. Desmostachya bipinnata L. Stapf, Hordeum vulgare L. and Drepanostachyum falcatum (Nees) Keng $f$. are three plants belonging to the family Poaceae having religious significance in different practices of Hinduism. They were also used as traditional medicines by our ancestors but nowadays they are underutilized. In this research, our core objective was to validate the traditional assumption of use of these plants in medicinal purposes by carrying out the assessments like antimicrobial assessment, antioxidative assessment and phytochemical assessment. Methanolic extracts produced from leaves of all three plants were examined for antimicrobial activities through agar well diffusion method. The same extracts were also assessed for determining their antioxidative potentials with the use of DPPH (1, 1-diphenyl-2-picryl hydrazyl) free radical scavenging assay followed by qualitative phytochemical analysis and GCMS (Gas Chromatography Mass Spectroscopy). Most promising antimicrobial activity was shown by Desmostachya bipinnata L. against Salmonella typhimurium and Staphylococcus aureus, Drepanostachyum falcatum (Nees) Keng f. against Salmonella typhimurium and Klebsiella pneumoniae and Hordeum vulgare L. against Salmonella typhmurium and Staphylococcus aureus. The antioxidant activity of the plant extracts were observed in descending order of Hordeum vulgare L.>Desmotachya bipinnata L. > Drepanostachyum falcatum (Nees) keng f. and phytochemical assessment of the extracts indicated the presence of alkaloids, glycosides, sterols, Triterpenes, Saponins, Flavonoids, Coumarins, Phlobatanin and reducing sugars. Through this project, we can clarify that the above mentioned plants have bioactive compounds which contributed for the presence of antimicrobial and antioxidative property in the plants.
\end{abstract}

Key words: Antimicrobial, Antioxidant, Desmostachya bipinnata L. Stapf, Drepanostachyum falcatum (Nees) Keng f., Phytochemical screening, Hordeum vulgare.

*Corresponding Author

Email: Pragya.nepal07@gmail.com

\section{Introduction}

Religions have created major linkage between human and nature by bounding human beings to several aspects of natural systems. All Hindu families in Nepal and India perform pujas (religious rituals) on certain occasions. There is no religious ritual, which does not require plants and their products [1]. Most of these plant species also have important medicinal value. For example; Ocimum tenuiflorum locally known as Tulasi is a holy plant having many religious significances and on the other hand, it has been used as a traditional medicine to cure common cold and flu. These kind of religious plants were involved by our ancestors in rituals to create a remark upon their importance as medicine or as a valuable product [2]. Now, we are unaware about the main reasons of use of these plants but we are still using them in religious purposes. Since, their uses have only been limited to religious practices; we tried to disclose the hidden medicinal importance of these plants by conducting different assessments on them. It is also reported that edible wild plants carrying religious importance such as, Ocimum tenuiflorum and Desmostachya bipinnata are the important source of fibre, vitamins, minerals and other nutrients which are used for the therapy of various diseases [3].

Desmostachya bipinnata L., belonging to family Poaceae is a perennial grass abundantly distributed in India. This plant is an important 
ingredient while performing 'hom', which is a sacred practice in Hindu rituals. Its root stock and leaves are used in Indian traditional system of medicine. Many medicinal properties and use of Desmostachya bipinnata L. have been reported in reference literatures [4].

Hordeum vulgare (Barley) is an annual grass from the Poaceae family and it is stated to be one of the earliest known crops to human kind. Barley seedling's leaves are locally called as Jamara and it is one of the most important plants in our greatest festival, Vijaya Dashami meanwhile, it is also traditionally used extensively to cure jaundice and gall bladder's stones. Barley is consumed for curing digestive disorders such as; diarrhoea, stomach pain and inflammatory bowel conditions.

Drepanostachyum falcatum (Arundinaria falcata Nees) is a common species of hill bamboo and is locally called as Nigalo. It is found in the homesteads in an abundant amount. This plant is used as an effective soil stabilizer for farming in Nepal and is used in religious practices like; Hindu marriage, house warming rituals etc.

\section{Materials and Methods \\ Plant materials}

Leaves of Desmostachya bipinnata (Kush), Hordeum vulgare L.(Jamara) and Drepanostachyum falcatum (Nees) Keng f. (Nigalo) were collected from Birgunj (located at Parsa District, Narayani zone), Kupandole (Located at Lalitpur district, Bagmati zone) and Balaju (Located at Kathmandu district, Bagmati zone) respectively during October of 2016.

\section{Extraction}

The collected leaves were first washed then dried in hot air oven at $40^{\circ} \mathrm{C}-70^{\circ} \mathrm{C}$ followed by grinding. Sample were dissolved in parts of $80 \%$ methanol in 1:3 ratios and placed in hot water bath shaker for 16 to 18 hours followed by filtration using muslin cloth [5]. The filtrate was stored and the residue was re-extracted under the same. The extracts obtained were pooled and filtered. The combined methanol specimen was evaporated to dryness using a vacuum rotary evaporator at $65^{\circ} \mathrm{C}$.

\section{GC-MS Analysis of Compounds present in plant extracts}

Gas Chromatography-Mass Spectrometry (GCMS) is a method, which combines the features of gas liquid chromatography and mass spectrometry to identify different substances present in a test sample [6].The process of GCMS was operated on GC-MS equipment i.e. Thermo GC-TRACE ultra ver: 5.0 and Thermo MS DSQ II. Features of the GC-MS system were; TR 5-MS capillary non-polar column having $35 \mathrm{Mts}$ dimension and thickness of film used in the process was $0.35 \mu \mathrm{m}$.Using Helium as the carrier gas, flow rate of the mobile phase was set at $1.0 \mathrm{ml} / \mathrm{min}$. In the gaschromatography section, prior temperature programme of $45^{\circ} \mathrm{C}$ was elevated to $255^{\circ} \mathrm{C}$ at $5^{\circ} \mathrm{C} / \mathrm{min}$ and $1 \mu \mathrm{l}$ sample was injected. Samples were first dissolved in chloroform to form a solution and were finally run at a range of 50 $655 \mathrm{~m} / \mathrm{z}$. The final results were compared by the use of Wiley Spectral library search programme.

\section{Phytochemical Screenings}

Qualitative phytochemical screening was carried out by using following standard protocols [7].

\section{Test for basic alkaloids (Dragondroff's test):}

$2 \mathrm{mg}$ of extract was dissolved in $3 \mathrm{ml}$ of $2 \%$ (v/v) HCL .To the solution, Dragondroff's reagent was added thoroughly. Appearance of orange brown precipitate indicated the presence of basic alkaloids.

\section{Test for glycosides:}

$100 \mu 1$ of glacial acetic acid was added to about $2 \mathrm{mg}$ of extract, followed by addition of few drops of $5 \%$ ferric chloride $\left(\mathrm{FeCl}_{3}\right)$. To the solution, few drop of $\mathrm{H}_{2} \mathrm{SO}_{4}$ was added until the formation of blue colour, which then, confirmed presence of glycosides.

\section{Test of Sterols and Triterpenes (Salkwoski's} test):

$2 \mathrm{mg}$ of extract was dissolved in $1 \mathrm{ml}$ of Chloroform. Later, $1 \mathrm{ml}$ conc. $\mathrm{H}_{2} \mathrm{SO}_{4}$ was added to the solution. Eventually, appearance of brown ring between junctions of two liquids 
indicated the presence of sterols and the brown ring with upper layer green indicated the presence of triterpenes.

\section{Test for Tannins and Polyphenol:}

$2 \mathrm{mg}$ extract was dissolved thoroughly in $1 \mathrm{ml}$ of water. To the solution, 3 drops of $1 \%(\mathrm{w} / \mathrm{v})$ ferric chloride $\left(\mathrm{FeCl}_{3}\right)$ was added. Appearance of blue black/ violet colour indicated the presence of Tannins and Polyphenols.

\section{Test for Saponins:}

$2 \mathrm{mg}$ extract was dissolved in $2 \mathrm{ml}$ of water. The solution was shaken vigorously for 30 minutes. Persistence of thick froth (about $1 \mathrm{~cm}$ ) height even after 30 minutes indicated the presence of saponins.

\section{Test for Flavonoids:}

To $2 \mathrm{mg}$ of extract, $5 \mathrm{ml}$ of $10 \% \quad(\mathrm{v} / \mathrm{v})$ Ammonium hydroxide $\left(\mathrm{NH}_{4} \mathrm{OH}\right)$ was added and to the solution, $1 \mathrm{ml}$ of conc. $\mathrm{H}_{2} \mathrm{SO}_{4}$ was added. Disappearance of yellow coloration indicated the presence of flavonoids.

\section{Test for Coumarins:}

$2 \mathrm{mg}$ extract was thoroughly dissolved in hot water of $2 \mathrm{ml}$. After cooling, the solutions were divided into two test tubes. To one of the test tubes, $10 \% \quad(\mathrm{v} / \mathrm{v})$ Ammonium hydroxide $\left(\mathrm{NH}_{4} \mathrm{OH}\right)$ was added until the solution became basic. The other test tube was used as control. The test tubes were kept under UV light. Fluorescence indicated the presence of Coumarins.

\section{Test for Phlobatanin:}

$1 \mathrm{mg}$ extract solution was boiled with $2 \mathrm{ml}$ of $1 \%$ HCL until the appearance of red precipitate was visible, which then, indicated the presence of Phlobatanin.

\section{Test for reducing sugars (Fehling's test):}

About $1 \mathrm{mg}$ of extract was mixed with $1 \mathrm{ml}$ of water. To this solution, $1 \mathrm{ml}$ of Fehling's reagent (1:1 mixture of Fehling's reagent $A$ and B) was added. Appearance of red precipitate indicated the presence of Phlobatatin.

\section{Antimicrobial Screening}

Antimicrobial screening was conducted by Agar well diffusion method. Sample was prepared by adding $25 \mathrm{mg}$ extract to $500 \mu \mathrm{l}$ of 100\% Dimethyl sulfoxide (DMSO) followed by 10-15 minutes of vortexing. $200 \mu \mathrm{l}$ of aforementioned DMSO solution was added to $200 \mu 1$ of double distilled water and was termed as 'Pure solution'. Again, pure solution was added to DMSO in $1: 1$ and 2:1 ratios. For positive control, antibiotics; Chloramphenicol, Tetracycline and Cefoxitin were used whereas, Imidazole prepared in DMSO $(0.1 \mathrm{~g} / \mathrm{ml})$ was used as antifungal agent. Similarly, for negative control $100 \%$ DMSO was used.

Bacterial inoculums were prepared in Nutrient Broth by taking a loop full of pure culture of microorganism and incubating them at $37^{\circ} \mathrm{C}$ for 3 hours. Turbidity of the broth was compared to Mcfarland turbidity standard number 0.5.

\section{Microorganisms used}

A total of seven reference microbial strains (three Gram negative bacteria; Escherichia coli ATCC 25922, Klebsiella pneunomiae ATCC 700603, Salmonella typhimurium ATCC 14028,one Gram positive bacteria; Staphylococcus aureus ATCC 25923 and four fungi; Fusarium spp., Trichoderma spp., Aspergillus flavus, Aspergillus niger) were used as the test organisms for the anti-microbial screening.

\section{Antibacterial Screening}

MHA (Mueller Hinton Agar) plates were swabbed with 3 hours broth culture using cotton swab. Wells of $6 \mathrm{~mm}$ were bored using sterile borer and $50 \mu \mathrm{l}$ of extract solution was poured using micropipette. The plates were kept for half an hour for diffusion in room temperature and incubated at $37^{\circ} \mathrm{C}$ for 24 hours. Anti-bacterial activity of each extract was expressed in terms of diameter of zone of inhibition $(\mathrm{mm})$ produced by respective extract against microorganisms after incubation. The procedure was done in replicate manner. 


\section{Antifungal Screening}

Fungal inoculums were prepared in PDB (Potato Dextrose Broth) by taking a loop full of pure culture of microorganisms and incubating them at $28^{\circ} \mathrm{C}$ for 24 hours. Petri plates containing PDA (Potato Dextrose Agar) were swabbed with 24 hours broth culture using cotton swab. Wells of $6 \mathrm{~mm}$ were bored using sterile borer and $50 \mu 1$ of extract solution was poured in them using micropipette. The plates were kept for half an hour at room temperature for diffusion and incubated at $28^{\circ} \mathrm{C}$ for incubation. The antifungal activity of each extract was expressed in terms of diameter of zone of inhibition $(\mathrm{mm})$ produced by respective extract against fungus after incubation.

\section{Antioxidant assay}

The antioxidant potentials of different extracts were determined using DPPH radical scavenging assay. Dry extract was dissolved in $1 \mathrm{ml}$ methanol at different concentrations $(100 \mu \mathrm{g} / \mathrm{ml}, 200 \mu \mathrm{g} / \mathrm{ml}, 300 \mu \mathrm{g} / \mathrm{ml}, 400 \mu \mathrm{g} / \mathrm{ml}$ and $500 \mu \mathrm{g} / \mathrm{ml}$ ) and was added to $4 \mathrm{ml}$ of $0.004 \%$ methanol solution of DPPH. After 30 minutes incubation at room temperature, the absorbance was read against a blank at 517nm in spectrophotometer (Cary $60 \mathrm{UV}-\mathrm{Vis}$ ) from Agilent technologies at NAST. Inhibition of free radical by DPPH in percent (\%) was calculated by using equation as:

$\mathrm{I}(\%)=\left[\left(\mathrm{A}_{\text {blank }}-\mathrm{A}_{\text {sample }}\right) / \mathrm{A}_{\text {blank }}\right] \times 100$, where $\mathrm{A}$ blank is the absorbance of control reaction (containing all reagents except the test compound and $\mathrm{A}$ sample is the absorbance of the test sample. Extract concentration providing $50 \%$ Inhibition $\left(\mathrm{IC}_{50}\right)$ was calculated from the graph plotted for inhibition percentage against extract concentration.

\section{Preparation of Ascorbic acid}

Ascorbic acid solution of $100 \mu \mathrm{g} / \mathrm{ml}, 200$ $\mu \mathrm{g} / \mathrm{ml}, 300 \mu \mathrm{g} / \mathrm{ml}, 400 \mu \mathrm{g} / \mathrm{ml}$ and $500 \mu \mathrm{g} / \mathrm{ml}$ were prepared in methanol.

\section{Screening of Anti-oxidant activity}

$1000 \mu \mathrm{l}$ of extracts solutions in methanol (100 $\mu \mathrm{g} / \mathrm{ml}, 200 \mu \mathrm{g} / \mathrm{ml}, 300 \mu \mathrm{g} / \mathrm{ml}, 400 \mu \mathrm{g} / \mathrm{ml}$ and $500 \mu \mathrm{g} / \mathrm{ml}$ ) was added to $4 \mathrm{ml}$ of $0.004 \%$ methanol solution of DPPH. After 30 minutes incubation at room temperature, the absorbance was read against a blank at $517 \mathrm{~nm}$ in spectrophotometer (Cary $60 \mathrm{UV}-\mathrm{Vis}$ ) from Agilent technologies. Inhibition of free radical by DPPH in percent (\%) was calculated by using equation as: $\mathrm{I}(\%)=\left[\left(\mathrm{A}_{\text {blank }}-\mathrm{A}_{\text {sample }}\right) / \mathrm{A}\right.$ blank] $\times 100$, where $A_{\text {blank }}$ is the absorbance of control reaction (containing all reagents except the test compound and $\mathrm{A}_{\text {sample }}$ is the absorbance of the test sample. Extract concentration providing $50 \%$ Inhibition $\left(\mathrm{IC}_{50}\right)$ was calculated from the graph plotted for inhibition percentage against extract concentration.

\section{Statistical Analysis}

Data are expressed as means and statistical analysis was performed with Microsoft excel 2010 and IBM SPSS Statistics 23. Difference on statistical analysis of data was considered significant at $\mathrm{P}<0.05$.

\section{Results}

\section{Analysis of GC-MS of Plant extracts}

The graph generated by Gas Chromatography showed composition of the extracts and the graph showed by Mass Spectrophotometer gave the percentage of each component (Figures 1, 2 and 3). The horizontal axis represented percentage area whereas the vertical axis represented the retention time of several components found in each extract. There were variations in retention time and percentage area of the three different extracts.

Total of 10, 32 and 28 compounds were identified through GC-MS from Desmostachya bipinnata L., Hordeum vulgare L. and Drepanostachyum falcatum (Nees) Keng f. respectively (Figures 1, 2 and 3). The major compounds found in Desmostachya bipinnata L. were 2,3 benzofuran dihydro and Octasiloxane, 1,1,3,3,5,5,7,7,9,9,11,11,13,13,15,15,-

hexacamethyl (Table 1) and the major compounds found in Drepanostachyum falcatum (Nees) Keng f. were Phenol 2, 6-dimethoxy, Benzoic acid and n-Hexadecanoic acid (Table 1). Similarly, compounds like Quinoline, Pthalic anhydride, 1, 2-Benzenedicarboxylic acid and Indole (Table 1) were identified in Hordeum vulgare. L.. The compounds were 


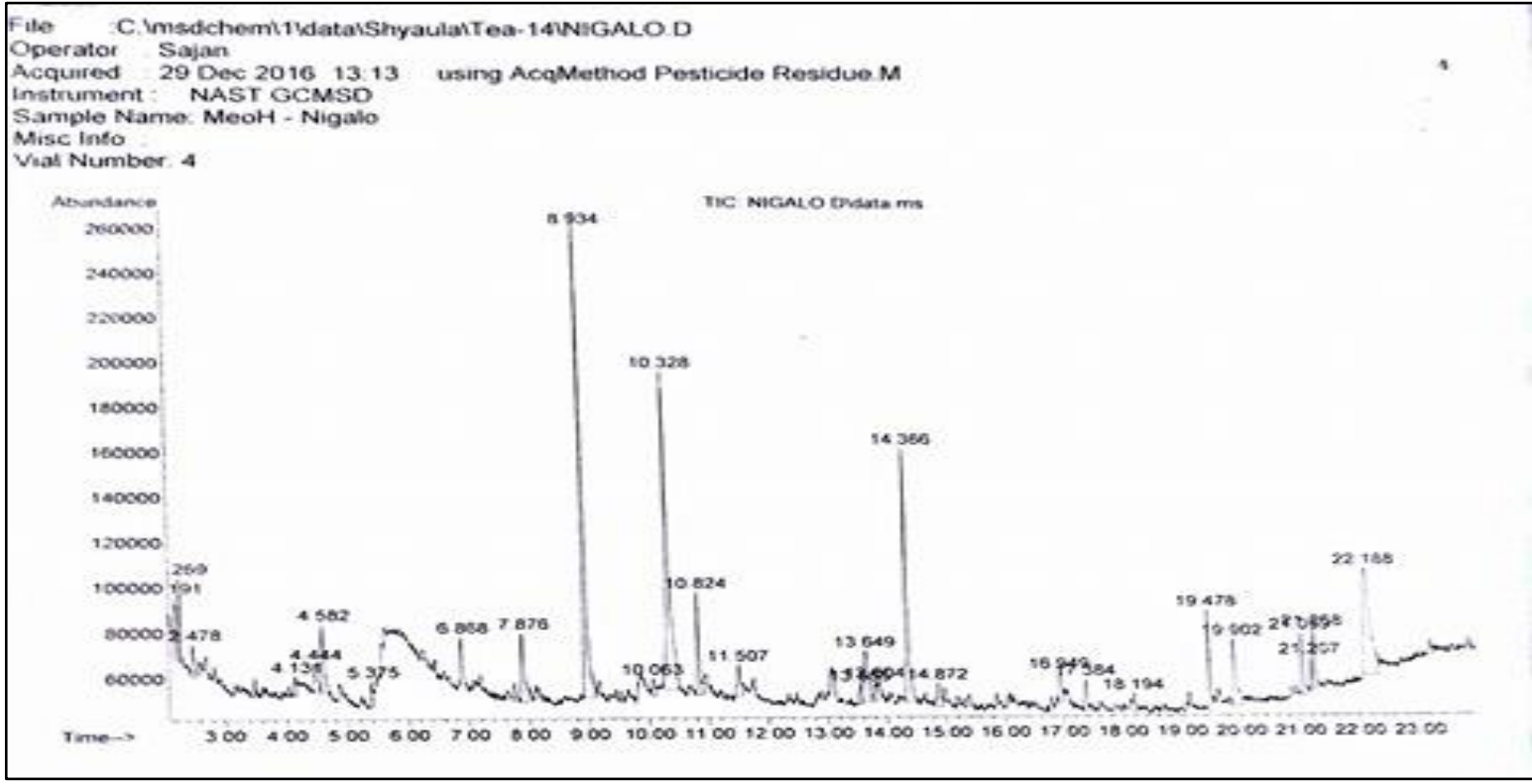

Figure 1: GC-MS graph for Drepanostachyum falcatum (Nees) Keng f

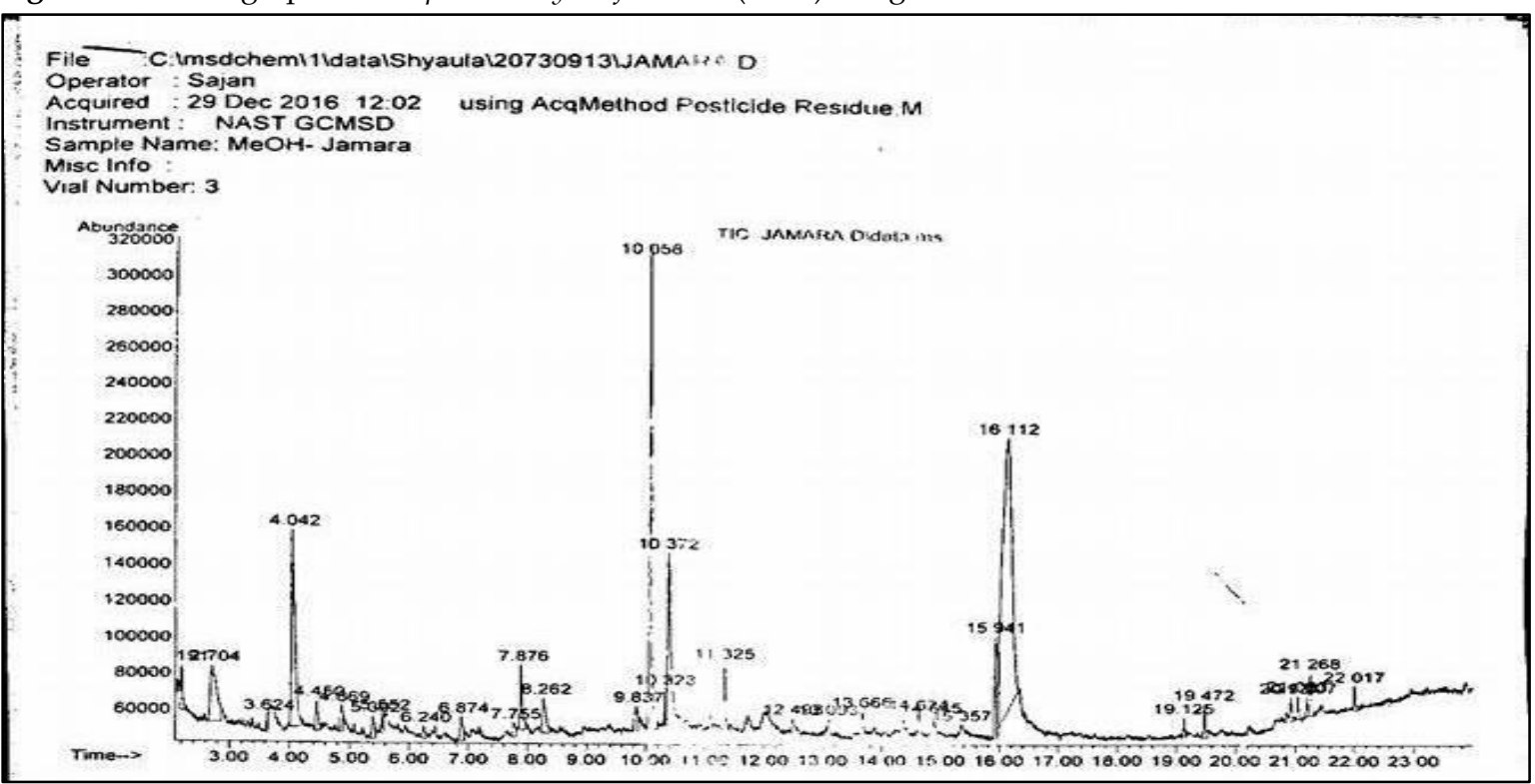

Figure 2: GC-MS graph for Hordeum vulgare L.

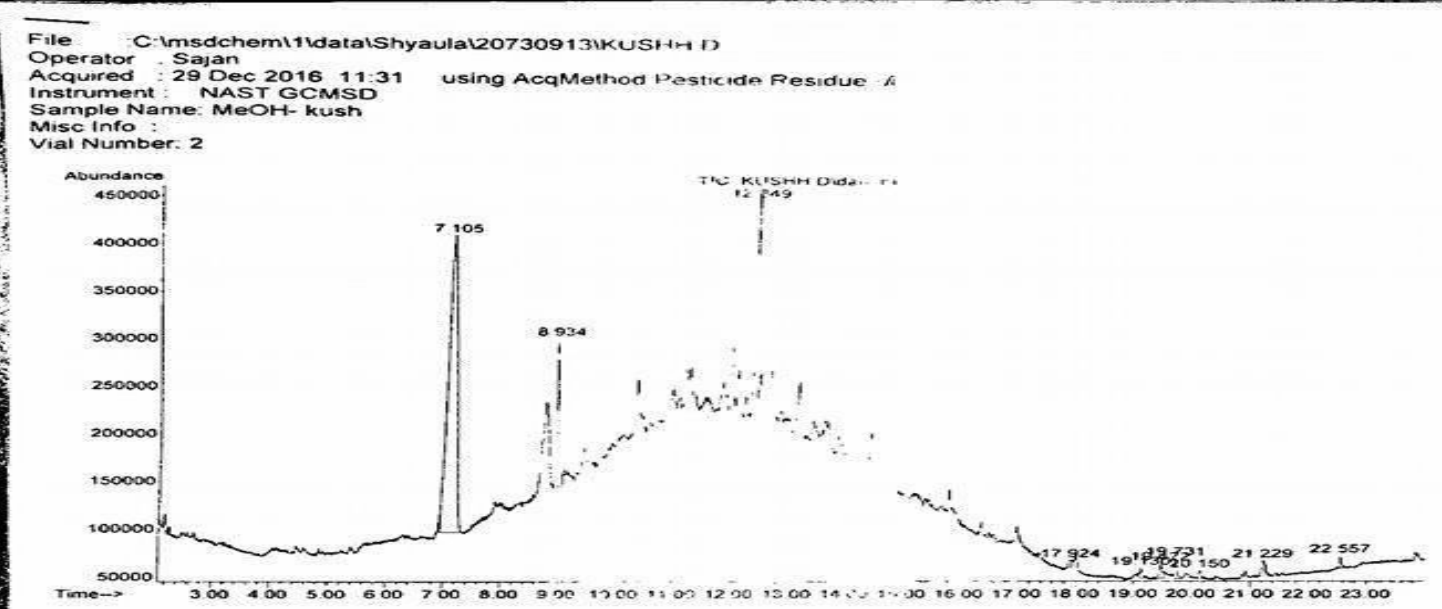

Figure 3: GC-MS graph for Desmostachya bipinnata L. 


\begin{tabular}{|c|c|c|c|c|}
\hline S.N & Extract & Name of compound & Retention factor & Peak area \\
\hline \multirow[t]{3}{*}{1} & \multirow{3}{*}{$\begin{array}{l}\text { Drepanostachyum } \\
\text { falcatum (Nees) Keng } \\
\text { f. }\end{array}$} & Phenol, 2, 6-dimethoxy & 10.823 & 95 \\
\hline & & Benzoic acid, 4-ethoxy, ethyl ester & 13.649 & 93 \\
\hline & & n-Hexadecanoic acid. & 19.478 & 98 \\
\hline \multirow[t]{3}{*}{2} & \multirow[t]{3}{*}{ Hordeum vulgare L. } & Phthalic anhydride & 10.372 & 95 \\
\hline & & 1H-Indole, 4-methyl & 11.325 & 94 \\
\hline & & Quinoline, 2-ethyl & 14.624 & 81 \\
\hline \multirow[t]{2}{*}{3} & \multirow{2}{*}{$\begin{array}{l}\text { Drepanostachyum } \\
\text { falcatum (Nees) Keng } \\
\mathrm{f}\end{array}$} & Benzofuran 2,3- dihydro & 8.934 & 56 \\
\hline & & $\begin{array}{l}\text { Octasiloxane, } \\
1,1,3,3,5,5,7,7,9,9,11,11,13,13,15,15,- \\
\text { hexacamethyl }\end{array}$ & 19.731 & 72 \\
\hline
\end{tabular}

Table 2: Phytochemical assessment of all three plant extracts

\begin{tabular}{llccc}
\hline S.N & Tests for Phytochemicals & Desmostachya bipinnata L. & $\begin{array}{c}\text { Plant extracts } \\
\text { Hordeum vulgare L. }\end{array}$ & $\begin{array}{c}\text { Drepanostachyum } \\
\text { falcatum (Nees) Keng f }\end{array}$ \\
\hline 1. & Basic Alkaloids & + & ++ & +++ \\
2. & Glycosides & ++ & - & +++ \\
3. & Sterols & + & ++ & +++ \\
4. & Triterpenes & + & - & ++ \\
5. & Tannis and polyphenols & - & - & + \\
6. & Saponins & + & ++ & + \\
7. & Flavonoids & ++ & ++ & ++ \\
8. & Coumarins & + & ++ & - \\
9. & Phlobatanin & - & ++ & +++ \\
10. & Reducing sugar & + & ++ & ++ \\
\hline
\end{tabular}

Index: $(+++)$ strongly positive, $(++)$ medium positive, $(+)$ weak positive and (-) negative

identified with the database of National Institute Standard and Technology. Majority of the compounds extracted from all three extracts belonged to hydrocarbon class. GC-MS results of Drepanostachyum falcatum (Nees) Keng $\mathrm{f}$. showed presence of wide range of compounds like saturated fatty acids like n-Hexadecanoic acid, unsaturated cyclic chemical compound like pyran-4-one, Aromatic organic compound like Syringol and Indene, ranges of Aldehydes like Vanillin and Benzaldehydes.

Similarly, the GC-MS result of Hordeum vulgare L. also showed the presence of Aromatic Heterocyclic organic compounds like Indole and Indolizine, Anhydrides of Thalic acid, heterocyclic aromatic organic compounds like; Quinoline and Pyrrole and other organic compounds like; Acetamide, Guanidine etc.

\section{Phytochemical Screening}

Phytochemical screening (Table 2) of Drepanostachyum falcatum (Nees) Keng f. showed presence of Alkaloids, Glycosides,
Sterols, Saponin, Coumarins and reducing sugar in good amount and Triterpenes in fair amount. Whereas, Hordeum vulgare L. extract contained phytochemicals like Alkaloid, Sterols, Saponins, flavonoids, Coumarins, Phlobatanin and reducing sugar in fair amount (Table 2). Similarly, Desmostachya bipinnata L. extract showed presence of Glycosides and Flavonoids in fair amount. From Table 2, presence of various phytochemicals in various amounts in the three plant extracts could be observed. Drepanostachyum falcatum (Nees) Keng f. showed presence of most of the phytochemicals in comparatively good amount than Hordeum vulgare L. and Drepanostachyum falcatum (Nees) Keng f.

\section{Antibacterial assay}

The antibacterial test showed a very promising result as all the extracts showed zone of inhibition against both gram positive and gram negative bacteria which was significantly comparable to the action of antibiotics against 


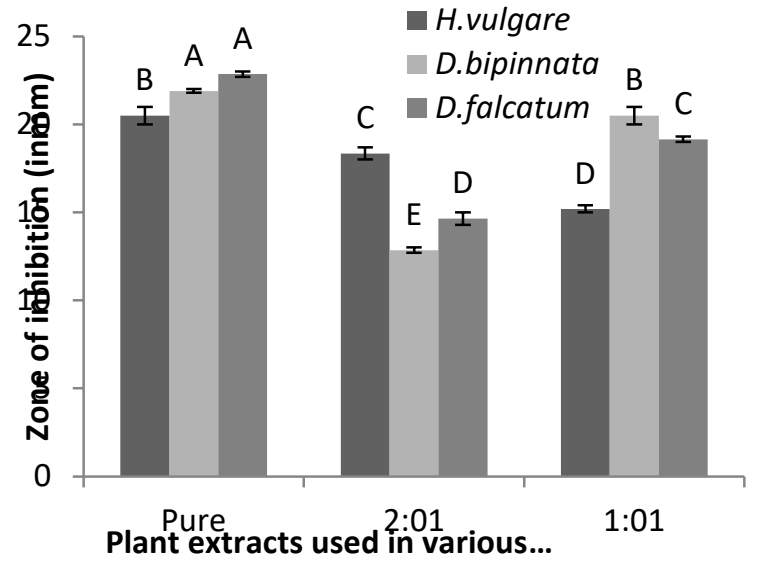

Figure 4: ZOI shown by various concentrations of the three extracts against Salmonella typhimurium

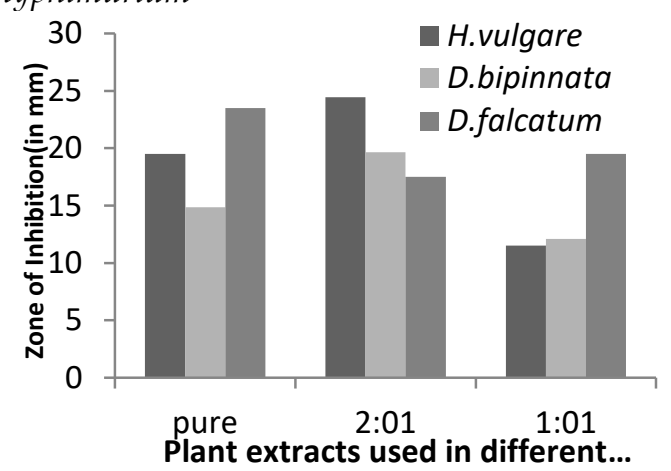

Figure 5: ZOI shown by various concentrations of the three extracts against Staphylococcus aureus.

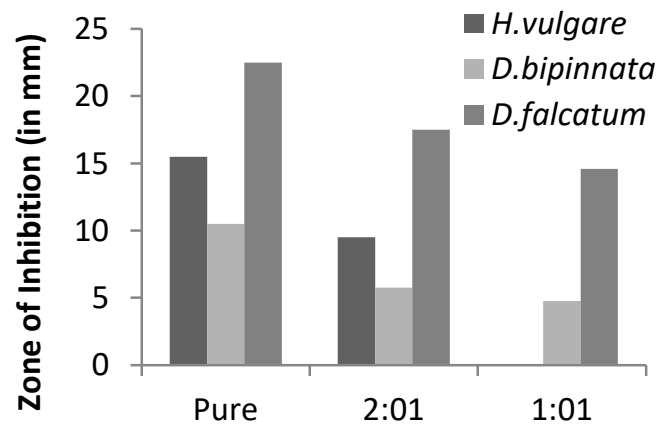

Plant extracts used in different concentrations

Figure 6: ZOI shown by various concentrations of the three extracts against Klebsiella pneumoniae.

bacteria. Most promising antimicrobial activity was shown by Desmostachya bipinnata L with zone of inhibition of $21.9 \mathrm{~mm}$ against Salmonella typhimurium and $19.65 \mathrm{~mm}$ against $S$. aureus (Figure 4 and 5). Hordeum vulgare showed zone of inhibition of $20.5 \mathrm{~mm} \mathrm{~L}$. against Salmonella typhi and of $24.45 \mathrm{~mm}$ against $S$. aureus (Figure 4 and 5). Drepanostachyum falcatum (Nees) Keng

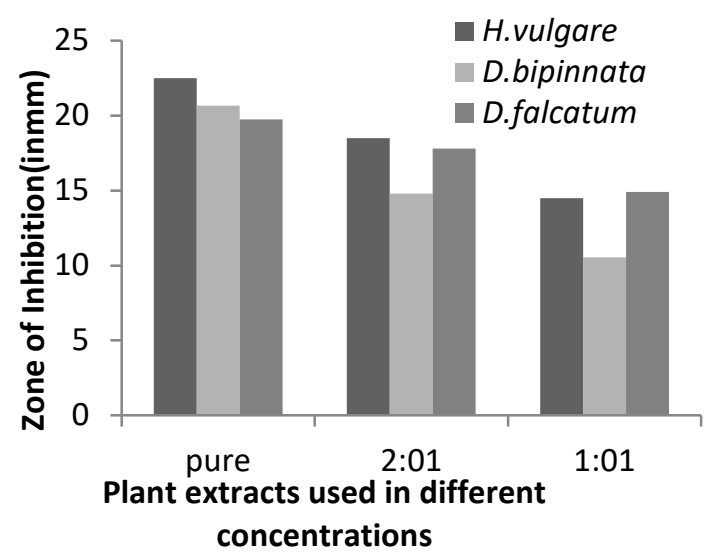

Figure 7: ZOI shown by various concentrations of the three extracts against $E$. coli.

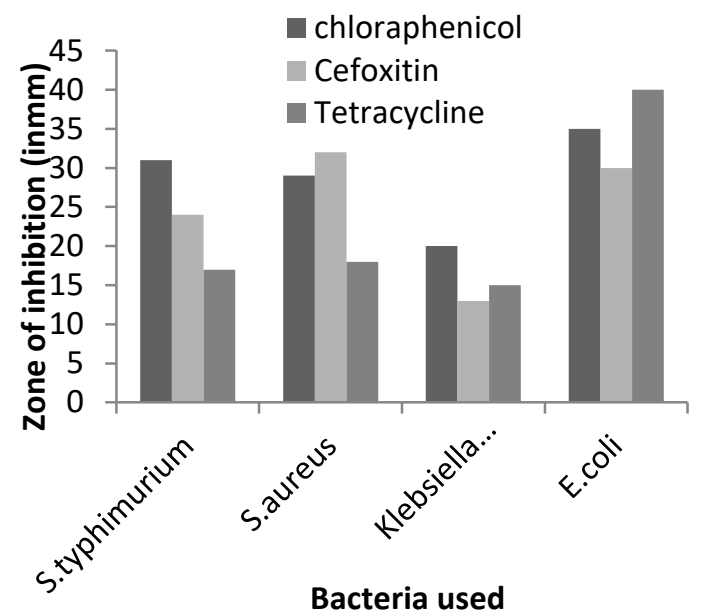

Figure 8: ZOI shown by Antibiotics against bacteria.

f. showed zone of inhibition of $22.85 \mathrm{~mm}$ against Salmonella typhi and $22.5 \mathrm{~mm}$ against klebsiella pneumonia (Figure 4 and 6). Hordeum vulgare showed zone of inhibition of $22.5 \mathrm{~mm}$ against E. coli (Figure 7). The zone of inhibitions shown by the extracts solution was compared to the zone inhibition showed by the antibiotics (Figure 8) Although, all three plants belonged to the same family Poaceae, the presence of biomolecules in each plant varied from another yet, all three plants showed a appreciable result against both gram-positive bacteria and gram negative bacteria.

\section{Antifungal assay}

In the case of Antifungal assessment, widest zone of inhibition of $15 \mathrm{~mm}$ was shown by sample 2:1 of Hordeum vulgare against Trichoderma spp. (Figure 9) and pure sample of 
Drepanostachyum falcatum against Fusarium spp.

(Figure 10).

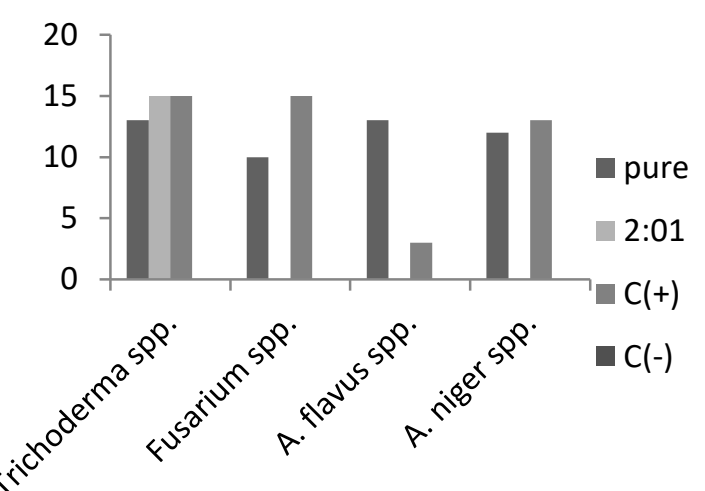

Figure 9: ZOI shown by Hordeum vulgare against fungus

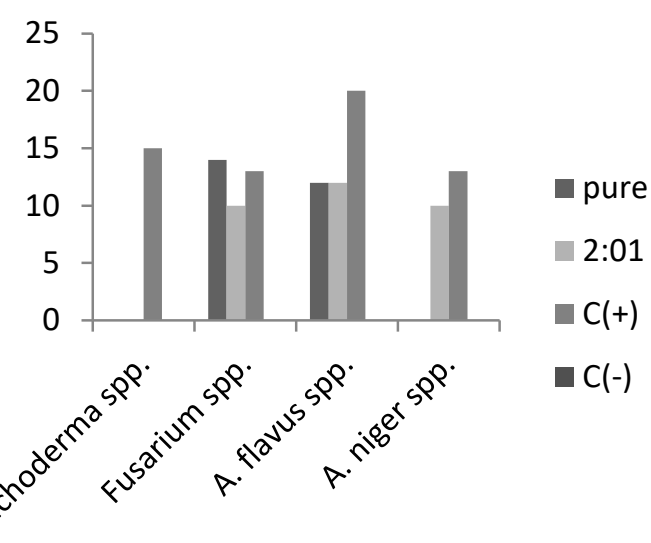

Figure 10: ZOI shown by Drepanostachyum falcatum against fungus

\section{DPPH radical Scavenging assay}

Table 3: $\mathrm{IC}_{50}$ values of Desmostachya bipinnata L., Hordeum vulgare L. and Drepanostachyum falcatum (Nees) Keng f.

\begin{tabular}{lll}
\hline S.N & Plant extracts & $\mathrm{IC}_{50}$ \\
\hline 1. & Desmostachya bipinnata L. & 143.36 \\
2. & Hordeum vulgare L. & 135.625 \\
3. & $\begin{array}{l}\text { Drepanostachyum falcatum } \\
\text { (Nees) Keng f }\end{array}$ & 590 \\
4. & Abscorbic Acid & 86.20 \\
\hline
\end{tabular}

In the DPPH method, the antiradical activity was evaluated by the capacity of antioxidant compound to reduce the DPPH radical as indicated by the decrease in its absorbance at $517 \mathrm{~nm}$ until the reaction reached a plateau. The antiradical activity was defined as the amount of antioxidant necessary to decrease the initial DPPH concentration by $50 \%$ [8]. The $\mathrm{IC}_{50}$ values of all the plant extracts and ascorbic acid (Table 3) illustrates that the antioxidant activity of the three plants extracts are in the descending order of Hordeum vulgare
L.>Desmotachya bipinnata L. > Drepanostachyum falcatum (Nees) keng f. DPPH radical scavenging assay of the three plants are graphically represented from figure 11-14. Hordeum vulgare L. and Desmotachya bipinnata L. were able to inhibit $50 \%$ concentration of $\mathrm{DPPH}$ radicals at $135.625 \mu \mathrm{g} / \mathrm{ml}$ and $143.36 \mu \mathrm{g} / \mathrm{ml}$ (Table 3) against, $\mathrm{IC}_{50}$ of the ascorbic acid's which was at $86.20 \mu \mathrm{g} / \mathrm{ml}$ (Table 3).

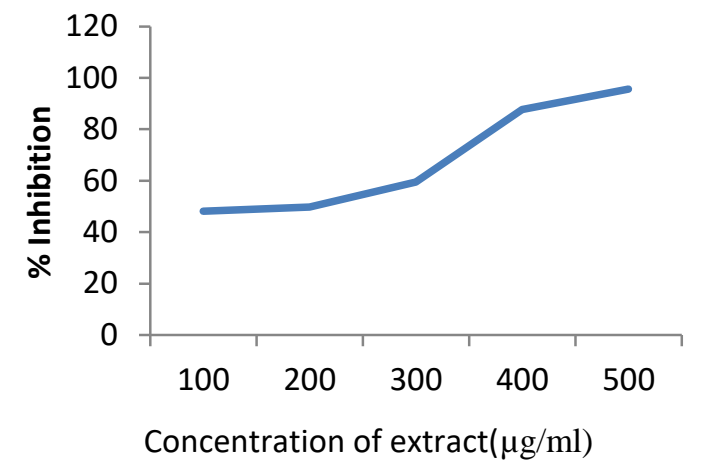

Figure 11: DPPH radical Scavenging assay of Desmostachya bipinnata L.

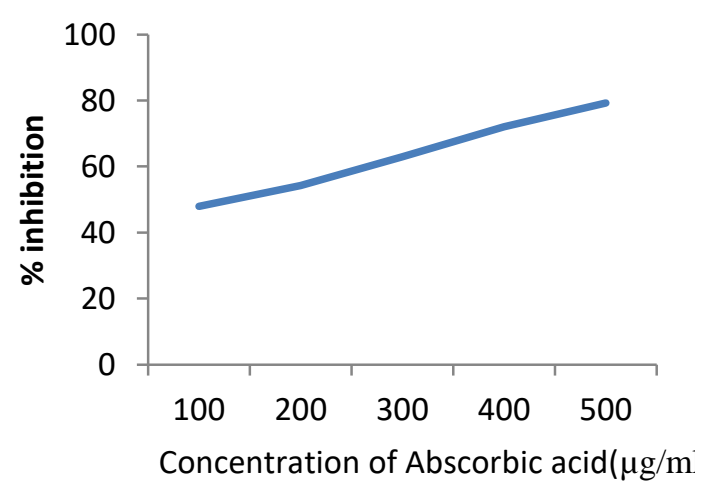

Figure 12: DPPH radical Scavenging assay of Hordeum vulgare L.

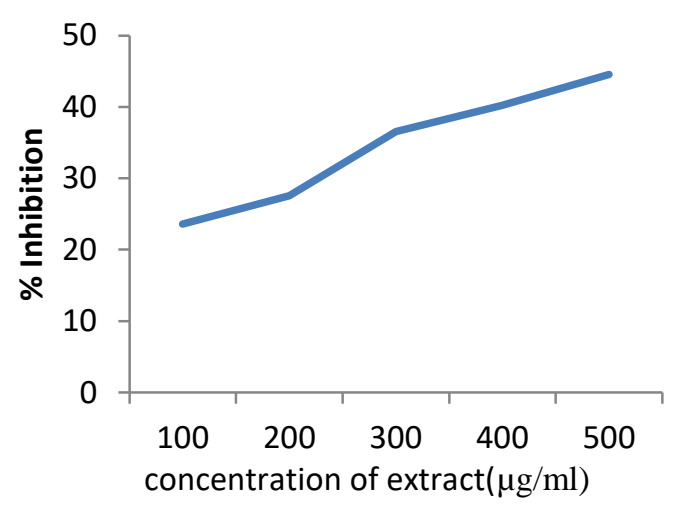

Figure 13: DPPH radical Scavenging assay of Drepanostachyum falcatum (Nees) Keng f. 


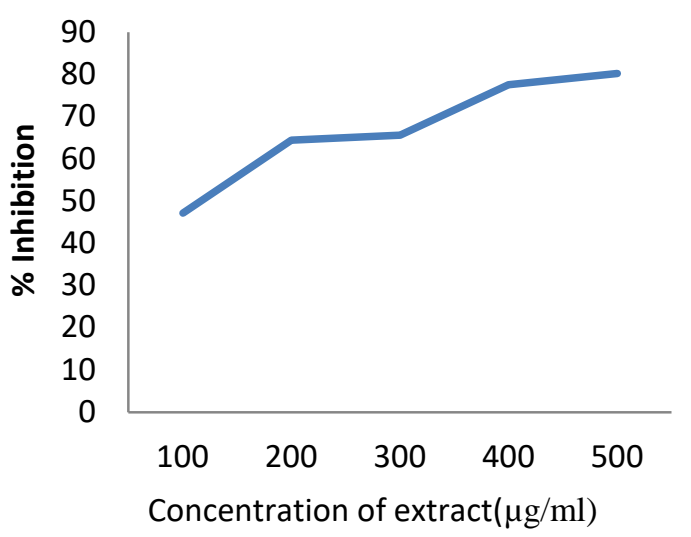

Figure 14: DPPH radical Scavenging assay of Ascorbic acid.

\section{Discussion}

The benzoic acid present in Drepanostachyum falcatum (Nees) Keng f.is a key component in prevention of infection caused by several bacteria. Compounds present in Desmostachya bipinnata L. such as, 4-hydroxynorephedrine is an active sympathomimetic metabolite of amphetamine in humans [9]. Amphetamine is a potent central nervous system (CNS) stimulant which have been used for treatment of attention deficit hyperactivity disorder (ADHD) [10].

Unlike our test sample, the result on essential oil of GC-MS of Desmostachya bipinnata L., conducted by Kumar \& Patel [10] showed the presence of 16 compounds with the similarity values ranging from $97 \%$ to $100 \%$ whereas, in our project only 10 compounds with much lesser similarity values (approx. 60\%) were observed. The reasons for these differences might be due to several variations in samples .As, our solution was in crude form whereas the other one was the essential oil. There is also a difference in extraction procedures and it may also be due to the differences in the geographical inheritance of the plants.

As a major class of natural products, alkaloids have been used in various parts of the world as a source of remedies to treat a wide variety of illnesses yet they are underrepresented in the context of newly introduced medicines [11]. Whereas, another group of glycosides i.e. Saponins are used widely for their effects on ammonia emissions in animal feeding and Saponins have also been used as adjuvants in vaccines e.g. Quil A; component QS-21, isolated from the bark of Quillaja saponaria Molina, to stimulate both the Th1 immune response and the production of cytotoxic T-lymphocytes (CTLs) against exogenous antigens [12].Phytochemical analysis showed presence of Coumarin in all three plant extracts where, Drepanostachyum falcatum (Nees) Keng f. showed strongly positive result.

In a research done by Kumar [13] for antimicrobial assay in essential oil of Desmostachya bipinnata, the diameter of the inhibition zone of oil of Desmostachya bipinnata varied from 15.2 to $56.2 \mathrm{~mm}$ where the largest zone of inhibition was obtained for $S$. epidermidis $(56.2 \mathrm{~mm})$ and lowest for $S$. aureus $(33.9 \mathrm{~mm})$ which is opposite to ours and the reason behind this could be dissimilarities in presence of phytochemicals due to condition from where the plant had originated including the difference in the temperature, humidity and other environmental stresses. Madineni [14] found that Thaumatin like proteins was extracted from barley have antimicrobial activity against Candida albicans, Bacillus subtilis, E. coli, Saccharomyces cerevisiae. Those proteins could be present in our samples too as we had good result upon E.coli. Antimicrobial assay verified that the plants rich in phytochemicals like saponins, coumarins, sterols, alkaloids and reducing sugars showed more promising results.

From this research, we figured out Antifungal properties of these plant extracts aren't as promising as Antibacterial properties. .Desmostachya bipinnata L. didn't show zone of inhibition against Aspergillus flavus and Aspergillus niger at all, although different concentration of plant extracts showed zone of inhibition against different fungus (table: 2).

Our research has also focused on the use of antioxidants, particularly, on the importance of naturally derived antioxidants, which may reduce free radicals, ROS production and may exhibit defensive property. The antioxidant activity of the three extracts were in the order of Hordeum vulgare L.>Desmotachya bipinnata L. 
$>$ Drepanostachyum falcatum (Nees) keng $\mathrm{f}$. The antioxidative effect was mainly due to phenolic components, such as phenolic acids and phenolic diterpenes [15]. Phenolic compounds have been proved to be responsible for the antioxidant activity in many medicinal plants.

\section{Conclusion}

The importance of religious plants is still prevailed in our society although scientific validation on use of these plants has not been done much. There was an urge to identify the bio-active compounds present in those plants for which we planned to conduct this project on religious plants.

Different bioactive compounds such as alkaloids, saponins, steroids, reducing sugars and glycosides were present in the plants. Plant which showed most promising result in phytochemical screening is Drepanostachyum falcatum (Nees) Keng f. Similarly, these plants also showed significant antioxidant property through DPPH radical scavenging assay. Since, the plants were rich in various phytochemicals; they had a moderate to significant antibacterial property but they showed quite weaker antifungal property which may be due to absence of some other bioactive compounds which were required to inhibit growth or kill the fungus. It can be concluded that the religious plants that we use in our daily life requires scientific validation for being use which can only done with research. These plants shouldn't only be limited to its religious practices, instead it could be used in multidisciplinary approaches. As we have shown in this project, the plants of religious value have important phytochemicals, antioxidative capacity and antimicrobial property, these plants could be also used in medicinal and therapeutic fields

\section{References}

1. Niroula G: Religion and Conservation: A Review of Use and Protection of Sacred. Journal of Institute of Science and Technology, 2015, 20(2): 61-66, IOST, Tribhuvan University.
2. Sapkota PP: Religious Culture and Medicinal Plants: An Anthropological Study. Dhaulagiri Journal of Sociology and Anthropology. 2013 7:197.

3. Dandapat S, Kumar M, Kumar A, Sinha MP: Therapeutic efficacy and nutritional potentiality of indian bay leaf (cinnamomum tamala buch. - hem.). Intnl J Pharm. (2013), 6.

4. Santhanam R, Okoro CK, Rong X, Huang Y, Bull AT, Andrews BA, Asenjo JA, Weon HY, Goodfellow M: Streptomyces deserti sp. Nov., isolated from hyper-arid Atacama desert soil. Antonie Van Leeuwenhowk, 20128

5. Chang-Geun K, Dae-Sik H, Young-Hwan K, Euikyung K, Jong-Shu K: Evaluation of Antimicrobial Activity of the Methanol Extracts from 8 Traditional Medicinal Plants. Toxicol Res. 2011 27(1)31-32.

6. kumar J, Kamajaj M, Nandagopalan V, Anburaja, V., \& Thiruvengadam, M. A Study of Phytochemical Constituents in Caralluma Umbellata. International Journal of Pharmaceutical Science Invention 201337.

7. Chhetri H, Yogol NS, Sherchan J, KC A, Mansoor S, \& Thapa P: Phytochemical and Antimicrobial Evaluations of some Medicinal Plants of Nepal. Kathmandu University Journal of Science, Engineering and Technology. 2008 4(1):49-54. https://doi.org/10.3126/kuset.v4i1.2883.

8. Lahouar L. Phytochemical content and antioxidant properties of diverse varieties. Food Chem. 2014581.

9. Santagati NA, Marrazzo A, Ronsisvalle G: Simultaneous determination of amphetamine and one of its metabolites by HPLC with electrochemical detection. I Pharm Biomed Anal. 2002 30(2):247-55.

10. Kumar A and Patel J: Chemical composition and antimicrobial activity of the essential oil of Coriandrum sativum. International Journal of Phytomedicine. 2010 436-439.

11. Vafa Amirkia MH: Alkaloids as drug leads - A predictive structural and biodiversity-based Analysis. Elsevier Phytochemistry letters, 2014 56.

12. Patrick H Demana, C. F. Effect of incorporation of the adjuvant Quil $A$ on structure and immune stimulatory capacity of liposomes. Immuno. Cell Biol., 20045.

13. Kumar AK, Sharvanee S, Patel J, Choudhary RK: Chemical composition and antimicrobial activity of the essential oil of Desmostachya bipinnata Linn. Int J Phytomed. 20104.

14. Jebor MA: Characterization and antimicrobial activity of barley grain. Int J curr microbiol Appl Sci 2013. 47.

15. Fereidoon SJP: Phenolic antioxidants CRC Critical Rev. Food Sci Nutr. 1992. 2:67-103. 